\title{
A Study on the Advantages and Application Strategies of Contemporary Red Films in College Belief Education
}

\author{
Lujun LV \\ Jilin Agricultural Science and Technology University, Jilin 132101, China \\ email: Ivlujun0357@163.com
}

Keywords: red film, belief education, function

\begin{abstract}
On behalf of the red film with its unique appeal advantage by the contemporary college students love that become an important resource for education in colleges .Effective and reasonable use of red film resources can effectively enhance the national identity of college students, national identity, improve the ideological level of college students, moral sentiments. The use of red film as an educational means in the classroom, activities and campus culture of colleges and universities will enhance the level of education in colleges and universities.
\end{abstract}

\section{Introduction}

In recent years, "Party Albert", "founding Albert," "Hundred Regiments", "Modern Peking Opera" and a number of red film stand a new height of China's rise through the screens it shows new expression for Chinese spirit, Chinese power, China confidence. In the youth gathered in the university set off a wave of red film "watch the tide", ignited the young students to pursue the red culture of "fire". The red film, as a specific type of film showing the Chinese revolutionary spirit and heroism, displays its history of revolution in China with its vivid, vivid and intuitive features, inspiring people's patriotic feelings and inspiring people to make a great rejuvenation of the Chinese dream Effort. Therefore, it has great significance to use red film to strengthen the belief education of college students and to guide college students to strengthen Marxist belief.

\section{The Present Situation of Contemporary Red Film's Dissemination in Colleges and Universities}

The General Office of the State Council and the State Council issued the Opinions on Further Strengthening and Improving the Propaganda and Ideological Work of Colleges and Universities in the New Situation. It is pointed out that in the "deepening of socialism with Chinese characteristics and Chinese dream education, strengthening the history and situation of the party history Task policy education, the core values of socialism into the whole process of higher education", which colleges and universities to strengthen the education of Marxist belief in education put forward new and higher requirements [1].

With the fiftieth anniversary of the founding of new China, the 90th anniversary of the founding of the People's Republic of China, the victory of the 70th anniversary of the victory of the Anti-Japanese War and the World Anti-Fascist War, Nanjing! "' October Fortress "," Party Albert "," Hundred Regiments "and a number of well-produced, star-studded red film landing the major theaters, as young students competing to watch the object [2]. The organization of college students will strengthen the ideological and political education of college students and cultivate the firm Marxist belief of college students through various forms such as "Red Film Show Week" and "Red Culture Month". According to the author in recent years to watch the red film on the study of students, about $90 \%$ of the students through the cinema, the way the network watched at least one red film; why watch the red film, 85\% of the students answer yes, the star Attracting more than 95\% of the students believe that the red film by reducing the history of the way, to reproduce the history, fascinating, greatly mobilized their interest in the red culture. Survey shows that the contemporary red film, a change 70, 80 years of narrative style, combined with advanced modern film and television technology, in accordance with the mode of operation of the market, by the college 
students' love. There is no doubt that contemporary film has become an important channel to strengthen the education of Marxist belief in college students.

\section{Advantages of Red Films in College Belief Education}

Red film in the hearts of generations of young students left a deep memory. This red memory has been deeply marked with the mark of the times. In different historical periods, the red film can set off people's "collective memory" of Chinese modern history. Contemporary red film with its unique advantages to become a beautiful film market in China, for the university to carry out Marxist belief education provides an important content [3].

The attractive advantage of contemporary red film. At present, the college students are the main body after 95 . They grow with the Internet, audio-visual environment, for a variety of information access channels more diversified. Through the network, wechat, microblog and other media access to the necessary information has become their own life style. Contemporary red film promotion strategy In addition to the traditional print media, pay more attention to the media in the field of film promotion. This is in line with the path of contemporary college students to understand the film information. Contemporary red film through the lighting, sound effects, montage and other performance techniques, with a strong star lineup, fine movie posters, well-designed actor costumes, wonderful story content to attract the attention of college students, so that students in the audio-visual scene, mood Happy to accept China's modern history education, Marxist belief education.

The entertainment advantages of contemporary red film. Successful films have dual functions of entertainment and education. In contrast to the contemporary red film changed 70, 80's red film style, not a single narrative-based, with a strong entertainment color, can make people enjoy the film in the process of enjoying the movie, to the heart Resonance and emotional communication. From this point of view, the art of cinema favored by the public is higher than other forms of art. The current college students face the pressure of academic, employment, social, family and other aspects, the need for emotional release, catharsis, communication space. The red film entertainment function allows college students not only to release their own pressure, but also from the correct belief in the value of the target

The Aesthetic Advantage of Contemporary Red Films. The pursuit of beauty is human assiduous. With the continuous enrichment of life experience, college students' aesthetic ability is increasing day by day. They judge the beauty of the ability to choose the beauty of the marked in the growing [4]. The unique aesthetic function of contemporary red film attracts college students. From the perspective of appreciation, the red film from the content to the form of in-depth grasp, feel the red film color beauty, scenes of the United States, bold beauty, action beauty, such as the film "founding" in the founding ceremony of the scene, the people festive new China Show the scene, people can't forget for a long time. Through the unique aesthetic appreciation of the red film, it will effectively promote the improvement of college students' aesthetic ability, so as to consciously choose the high artistic value of the film.

\section{The Role of Red Film in the Education of Belief in Colleges and Universities}

The contemporary college students are the builders and successors of the cause of socialism with Chinese characteristics. It is great strategic significance to strengthen their education of Marxist belief. Marxist belief education is the essence of ideological and political education in colleges At present, the content of Marxist belief education is pointed out by the general secretary of Xi Jin ping. "The Chinese dream is the common ideal of the people of all nationalities and the ideal pursuit that the younger generation should firmly establish. Socialism with Chinese characteristics is the right path for our party to lead the people through hardships to find the realization of the Chinese dream, but also the contemporary youth should firmly establish belief in life. However Contemporary red film has an irreplaceable role in strengthening the education of faith in colleges and universities.

Help to improve the college students' national identity. National identity is the social individual 
to their own people's cognition, feelings and behavior of the attachment, with a sense of belonging to the nation. The ideological situation of contemporary college students is influenced by the influence of western culture, and the degree of recognition of the nation has been reduced, and the recognition degree of its own nation needs to be further strengthened. Many contemporary red films are often from the perspective of the survival of the nation, revealing the development of national destiny. For example, the red film "Party Albert" young students for the country, the future of the nation to actively explore, bold practice, whether nationalism, anarchism, or positivism, Scientism and other social trends, are the advanced Chinese people The Difficult Exploration of Ethnic. College students through this kind of red film viewing, will be strong to enhance the identity of the people, to understand the development process of the Chinese nation at stake, establish national self-confidence, Chinese self-confidence.

Help to improve the college students' national identity. For the individual, the national identity means that the individual mentally believes that he belongs to the political community and is aware of his or her identity as a member of the country. In the period of continuous development of economic globalization and social transformation, the beliefs of college students show the characteristics of religion, pluralism and utilitarianism. Many college students agree with the development path of western countries and need to be further improved. Mainstream red film with fresh facts to answer the voice of college students questioned. For example, "the founding of the great cause" in the film, the Chinese Communist Party and the Chinese Kuomintang around the founding of the different strategies adopted by Western countries, the external forces of interference [5]. Through the observation of such films, students can understand the difficulties of the establishment of new China, deepen the national identity, strong resistance to Western "peaceful evolution" of the infiltration.

Help to enhance the ideological realm of college students. Excellent film can enrich the inner world of people, enhance people's ideological realm. According to the survey, the average person's daily concerns of Internet time is three hours, students use the Internet at a time is much larger than this number, but most attention to the circle of friends, micro letter, QQ, Really effective use of the Internet time is relatively small. The leaders of the red film, heroes have a charming personality charm, such as the realm of gold thinking is worth learning from college students learn. The film "Zhou Enlai's four day and night" tells the story of Zhou Enlai came to the revolutionary old liberated areas of Hebei Handan Bo Yan commune investigation and study, in the four day and night time kept working, the moment is not wasted, through visits with local farmers in the village , Discussion, research successfully solve the problems of the commune. Through this kind of red film learning to watch, you can effectively strengthen the concept of college students, can enhance the ideological level of college students to serve the people, the realm of life.

Help to improve the moral education of college students. College students are in the formation of values, for true and false, good and evil, right and wrong, straight with a certain degree of appreciation, discrimination. Excellent red film through the image of a typical character portrayed, the story of the true and false straight to his right. Mao Zedong went to Chongqing to discuss the founding of the country, but a side of the negotiations, while suppressing the Chinese Communist Party, people read after the very angry, and the Chinese Communist Party in their own sincerity to invite the middle democratic parties to participate in the founding of the great cause, for the The invitation of the activist Soong Ching Ling was touched, especially when Song Qingling arrived in Beijing Railway Station, Chairman Mao Zedong personally greeted, people can not doubt the sincerity of the Chinese Communist Party democracy. Through this kind of red film viewing, can effectively enhance the student's moral sentiment, know what is true and the beautiful, what is false ugly, know how to do a honest and kind, sincere person.

\section{The Application of Red Film in College Belief Education}

Use red film is in order to carry out classroom education. The main channel of faith education in the classroom, the ideological and political theory teacher is the subject of the implementation of faith education. In recent years, the ideological and political theory of teaching methods have undergone 
great changes, is no longer a single way of preaching, for the use of multimedia by college students welcome. Many colleges and universities ideological and political theory teachers actively explore the use of students happy to accept the way to carry out Marxist belief in education, ideological and political theory in the course of teaching, focusing on the red film of this art form and classroom knowledge about the organic collection, get more praise from students. For example, in the "Outline of China's modern history" in the process of "founding party Albert", "Jianguo Albert", "Hundred Regiments" and other fragments of red movies and explain the knowledge point of a high degree of fit, the film moderate play Not only can effectively alleviate the students tired of lectures, but also can make students pay more attention, and in this way students can get impressed, easy to understand.

Use red film for community activities. In recent years in the construction of colleges and universities, the construction of the red community mushroomed in general. At present, the activities of the Red Community are mainly based on theoretical lecture, the effect is unsatisfactory, the attractiveness of the students is not enough. If you can better use the essence of the red film, the integration of community resources, the students in accordance with the different roles to interpret the red characters, micro-film way to broadcast their performances, will be able to received from students. In the process of red micro-film shooting, the actor is bound to carefully figure out the characters of the language style, to understand the character of the introduction, to imitate the characters of the body language, this is undoubtedly deepened the students for the red film content of the memory, The level of people's awareness.

Use the red film to carry out film critic activities. Every year the college students Film Festival are subject to college students attention and sought after. Appreciation of excellent movies has become a way of life for college students. Many colleges and universities will use major anniversaries or important festivals, such as praise the Eighth Route Army soldiers bravely fighting against the Japanese invaders feat "Hundred Regiments" is playing in the Chinese people's war of resistance against Japan and the anti-fascist war on the eve of the 70th anniversary of the victory, Regularly held "red film broadcast week" activities to prize essays, lectures, seminars and other forms of film and television activities. In this way, faith education becomes more specific, there is a grasp, step, and effective, students are higher than the ideological education.

Use red film to enrich red culture. The campus is the main place for college students to study. Colleges and universities should play the campus environment education function, highlight the campus culture, so that the campus culture, such as spring and rain like the growth of students heart. General Secretary Xi Jinping on many occasions repeatedly pointed out that "let the red gene from generation to generation", so the campus culture construction in the "red" word up and down enough effort, carefully designed college students to accept the Marxist belief in education environment, in the red culture of publicity Highlight the history and the combination of the times, the red film initiative into the red culture of the building, from the campus publicity board, radio, wechat platform, campus sites and other aspects of construction, so that students consciously into the red culture atmosphere, Take the initiative to accept the education of faith.

In points of the above, colleges and universities should effectively use the red film in the education of college students to promote the construction of campus culture, give full play to the red film in classroom teaching, student activities in the unique advantages of college students to actively guide the red film Vector, so that the red gene into the blood of college students, to become the cause of socialism with Chinese characteristics to cultivate qualified builders and successors [6].

\section{Acknowledgement}

Fund program: Jilin Agricultural Science and Technology university 2014 Youth Fund Project (Focus), "A Study on the Present Situation and Countermeasures of College Students' Belief in Jilin Province” (Kyrgyzstan Agricultural Union word \{2014\} No. 102). 


\section{References}

[1] The General Office of the State Council and the General Office of the State Council on Further Strengthening and Improving the Ideological and Political Work in Colleges and Universities under the New Situation[N].People's Daily, 2015-1-20..

[2] Yu He Nan. General Secretary of the Communist Party of China: the world and China's perspective [N]. Guangming Daily, 2016-2-13.

[3] WANG Fu-xin, YI Li-yun. Discussion on the Concept and Level of National Identity [J]. Qinghai Ethnic Studies, 2011 (01) 36..

[4] Guo Yan. Post-development countries in the era of globalization: national identity encounters "de-centralization" [J]. World Economy and Politics, 2004 (09). 38-41.

[5] Xiong Ying .On the rationality of College Students' belief education [J].. Wuhan Technology University Journal, 2015 (06)22-27.

[6] Gao San..Reflections on the belief education of college students [J]. Education and profession. 2016 (22)15-19. 